\title{
RADIOCARBON DATING OF MAKURI LÊ BOOM, A VERY OLD AFRICAN BAOBAB FROM NYAE NYAE, NAMIBIA
}

\author{
ROXANA T. PATRUT'a, ADRIAN PATRUT ${ }^{\mathrm{b}, c *}$, \\ DEMETRA RAKOSY ${ }^{d}$, LASZLO RAKOSYa, DANIEL A. LÖWYe, \\ JENŐ BODIS ${ }^{b, c}$, KARL F. VON REDEN ${ }^{f}$
}

\begin{abstract}
The article reports the AMS (accelerator mass spectrometry) radiocarbon dating results of Makuri Lê boom, a very large African baobab from Nyae Nyae Conservancy, Namibia. The investigation of this superlative baobab shows that it consists of 12 independent stems of different dimensions, which belong to three generations. Makuri Lê boom has an open ring-shaped structure, a type of architecture which allows baobabs to reach very large sizes and old ages. The oldest sample has a radiocarbon date of $1602 \pm 17 \mathrm{BP}$, which corresponds to a calibrated age of $1520 \pm 35$ calendar yr. By this value, Makuri Lê boom becomes one of the oldest dated baobabs and angiosperms with accurate dating results.
\end{abstract}

Keywords: AMS radiocarbon dating, Adansonia digitata, tropical trees, dendrochronology, age determination, multiple stems.

a Babeş-Bolyai University, Faculty of Biology and Geology, 44 Republicii, RO-400015, ClujNapoca, Romania

${ }^{b}$ Babeş-Bolyai University, Faculty of Chemistry and Chemical Engineering, 11 Arany Janos, RO-400028, Cluj-Napoca, Romania

c Babeş-Bolyai University, Raluca Ripan Institute for Research in Chemistry, 30 Fantanele, RO-400294 Cluj-Napoca, Romania

d AG Spatial Interaction Centre, German Centre for Integrative Biodiversity Research, 5e Deutscher Platz, D-04103 Leipzig, Germany

e VALOR HUNGARIAE, Dept. of Science and Innovation, 4 Nagysándor József, 1054 Budapest, Hungary

${ }^{f}$ NOSAMS Facility, Dept. of Geology \& Geophysics, Woods Hole Oceanographic Institution, Woods Hole, MA 02543, U.S.A.

*Corresponding author: apatrut@gmail.com 
ROXANA T. PATRUT, ADRIAN PATRUT, DEMETRA RAKOSY, LASZLO RAKOSY, DANIEL A. LÖWY, JENŐ BODIS, KARL F. VON REDEN

\section{INTRODUCTION}

The African baobab (Adansonia digitata L.), which belongs to the Bombacoideae subfamily of Malvaceae, is the best known, the most utilized and widespread of the eight or nine species of the Adansonia genus. One or two species are endemic to the arid savanna of mainland Africa, six species are restricted to Madagascar and one species has a natural distribution in Australia [1-5].

In 2005, we started an extended research project to clarify several controversial aspects related to the architecture, development and age of the African baobab. Our approach consists of AMS (accelerator mass spectrometry) radiocarbon dating of tiny wood samples extracted from inner cavities, deep incisions in the stems, fractured stems and from the outer part/exterior of large baobabs [6-17]. Research results show that young baobabs are usually single-stemmed individuals, which develop into multi-stemmed trees, owing to their ability to generate new stems over time. We also established that superlative baobabs, i.e., very large and old specimens, preferentially exhibit ring-shaped structures. The oldest African baobabs were found to have ages up to 2,500 years. Thus, the African baobab becomes the longest-living angiosperm $[9,11,13-15]$.

In 2013, our investigation on baobabs was extended to large and old individuals of the most representative three species of Madagascar, i.e., Adansonia rubrostipa Jum. \& H. Perrier (Fony baobab), Adansonia za Baill. (Za baobab) and Adansonia grandidieri Baill. (Grandidier baobab) [19-22].

Namibia hosts several very big and old African baobabs. Most of them are in the north-east, in an area known during the colonial apartheid era as Bushmanlad, after its inhabitants. In 1990, after the end of the Independence War (also called South African Border War), South West Africa became Namibia. Since then, the new name of Bushmanland is Tsumkwe District and it is part of the Otjozondjupa region. The small town of Tsumkwe, which is the district capital, is the centre of the area populated by the Ju/'hoansi; they belong to the San people, also known as Bushmen.

We investigated and dated several African baobabs around Tsumkwe. Four of them have or had very large dimensions and ages between 1200 and 2000 years, namely Dorslandboom, Holboom, Grootboom and Makuri Campsite baobab $[6,9,13,18]$. In a paper dedicated to the largest and oldest African baobabs, we mentioned the name of another very old tree in this region, the Makuri Lê boom [9]. Makuri Lê boom is the sixth oldest known African baobab with accurate dating results. Here we present the investigation and the radiocarbon dating results of this impressive baobab. 


\section{RESULTS AND DISCUSSION}

The Makuri Lê boom and its area. The big baobab is located in the Nyae Nyae Conservancy, established in 1998, around the Nyae Nyae Pans. The Conservancy covers the eastern part of the Tsumkwe district (Bushmanland), up to the border of Namibia with Botswana. The baobab is situated at $32 \mathrm{~km}$ ESE of Tsumkwe, $9 \mathrm{~km}$ SE from the Makuri village and $10 \mathrm{~km} \mathrm{SW}$ from the Baraka village. Its GPS coordinates are $19^{\circ} 39.404^{\prime} \mathrm{S}, 020^{\circ} 47.143^{\prime} \mathrm{E}$ and the altitude is $1169 \mathrm{~m}$. The mean annual rainfall in the area is $467 \mathrm{~mm}$, while the mean annual temperature reaches $21.5^{\circ} \mathrm{C}$ (Tsumkwe station). The investigated baobab is a "laying tree", i.e., "Lê boom" in Afrikaans, such as the famous Dorslandboom, which can be found at $35 \mathrm{~km}$ NNE of Tsumkwe $[13,18]$. We named it Makuri Lê boom.

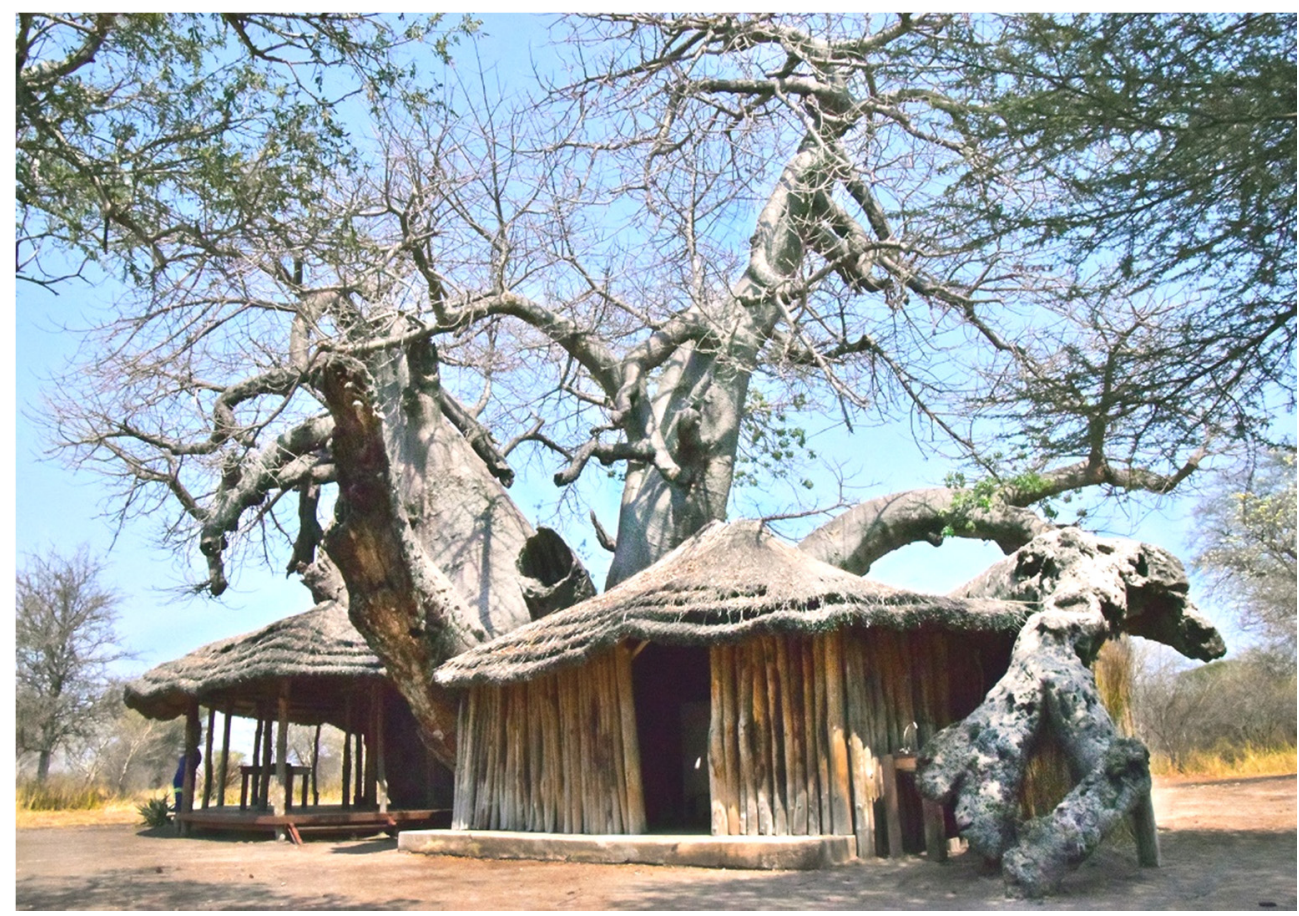

Figure 1. Makuri Lê boom with the auxiliary constructions of the hunting camp around its stems. 
This monumental baobab, which grows in the proximity of a manmade waterhole, is known only at a local level by a limited number of San natives and a few hunters from Europe and America. Around and in between its stems there is a very unusual hunting camp, exclusively used a few times every year by rich hunters arriving here by private jets (Figure 1). In this area, they hunt the biggest African elephants and sometimes lions and leopards.

Makuri Lê boom exhibits an original structure, composed of 12 living stems of different dimensions and ages. Two stems are toppled, broken and lying on the ground, but still alive, 4 stems are leaning and severely broken/fractured, while the other 6 standing stems have many missing branches. The stems are partially blackened by previous fires. Several stems are missing. The stem numbering is presented in Figure 2.

This peculiar-looking baobab has an impressive circumference at breast height (cbh; at $1.30 \mathrm{~m}$ above ground level) of $34.23 \mathrm{~m}$, the maximum height of the standing stems is $14.5 \mathrm{~m}$ and the overall wood volume (stems and branches) is around $200 \mathrm{~m}^{3}$. The horizontal dimensions of the severely damaged canopy are 26.4 (NS) $\times 25.5$ (WE) $\mathrm{m}$.

Wood samples. Two tiny wood samples (marked as a and b), with the mass between $1-5 \times 10^{-4} \mathrm{~kg}$, were extracted from determined positions of 3 different stems each, by using a sharp instrument. The samples were labelled according to the initials of the tree name and the corresponding stem number, i.e., ML-1, ML-8 and ML-11.

AMS results and calibrated ages. Radiocarbon dates of the 6 samples are listed in Table 1 . The radiocarbon dates are expressed in ${ }^{14} \mathrm{C}$ yr BP (radiocarbon years before present, i.e., before the reference year 1950). Radiocarbon dates and errors were rounded to the nearest year.

Calibrated (cal) ages, expressed in calendar years CE (CE, i.e., common era), are also shown in Table 1 . The $1 \sigma$ probability distribution $(68.2 \%)$ was selected to derive calibrated age ranges. For three samples (1a, $8 a, 11 b)$, the $1 \sigma$ distribution is consistent with one range of calendar years. For the other three segments $(1 \mathrm{~b}, 8 \mathrm{~b}, 11 \mathrm{a})$, the $1 \sigma$ distribution is consistent with two ranges of calendar years. In these cases, the confidence interval of one range is considerably greater than that of the other; therefore, it was selected as the cal CE range of the sample for the purpose of this discussion. For obtaining single calendar age values of samples, we derived a mean calendar age of each sample from the selected range (marked in bold). 
RADIOCARBON DATING OF MAKURI LÊ BOOM, A VERY OLD AFRICAN BAOBAB

FROM NYAE NYAE, NAMIBIA

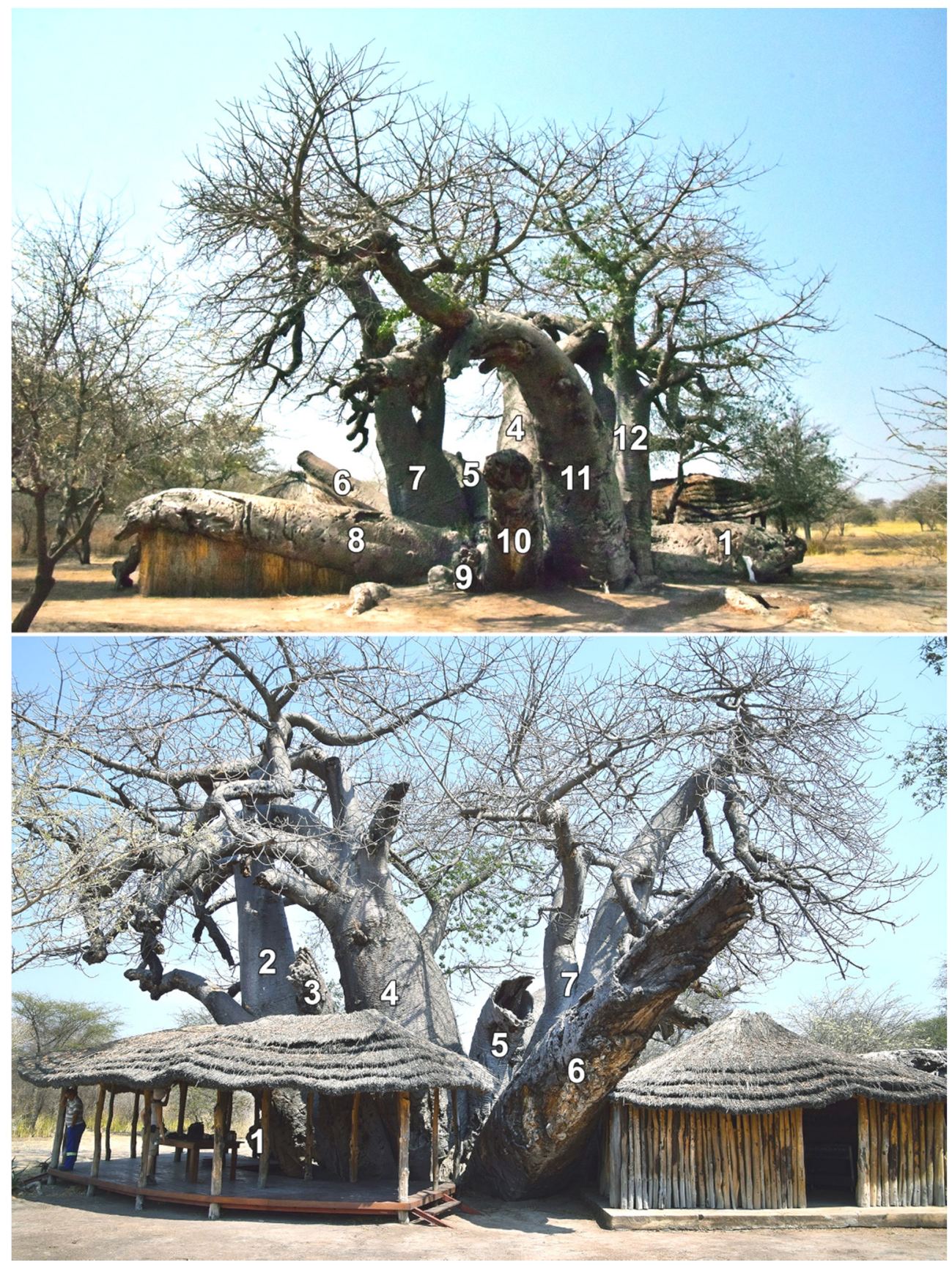

Figure 2. General view of Makuri Lê boom from the west (top) and from the east (bottom), with stem numbering. 
ROXANA T. PATRUT, ADRIAN PATRUT, DEMETRA RAKOSY, LASZLO RAKOSY, DANIEL A. LÖWY, JENŐ BODIS, KARL F. VON REDEN

Table 1. Radiocarbon dating results and calibrated ages of samples collected from Makuri Lê boom

\begin{tabular}{|c|c|c|c|c|c|}
\hline $\begin{array}{l}\text { Sample } \\
\text { code } \\
\text { (stem) }\end{array}$ & $\begin{array}{l}\text { Depth }^{1} \\
\text { [height } \\
\text { (m) }\end{array}$ & $\begin{array}{c}\text { Radiocarbon } \\
\text { date [error] } \\
\left({ }^{14} \mathrm{C} \text { yr BP) }\right.\end{array}$ & $\begin{array}{l}\text { Cal CE range 1 } \sigma \\
\text { [confidence } \\
\text { interval] }\end{array}$ & $\begin{array}{c}\text { Assigned } \\
\text { year } \\
\text { [error] } \\
\text { (cal CE) }\end{array}$ & $\begin{array}{c}\text { Sample } \\
\text { age } \\
\text { [error] } \\
\text { (cal CE) }\end{array}$ \\
\hline $\begin{array}{l}\mathrm{ML}-1 \mathrm{a} \\
(1)\end{array}$ & & $1090[ \pm 18]$ & $994-1016$ (68.2\%) & & \\
\hline $\begin{array}{l}\text { ML-1b } \\
(1)\end{array}$ & $\begin{array}{c}1.02 \\
{[4.20]}\end{array}$ & $1602[ \pm 17]$ & & $\begin{array}{c}502 \\
{[ \pm 35]}\end{array}$ & $\begin{array}{l}1520 \\
{[ \pm 35]}\end{array}$ \\
\hline $\begin{array}{c}\text { ML-8a } \\
(8)\end{array}$ & $\begin{array}{c}0,45 \\
{[6.50]}\end{array}$ & $930[ \pm 19]$ & $1152-1200(68.2 \%)$ & $\begin{array}{c}1176 \\
{[ \pm 25]}\end{array}$ & $\begin{array}{c}845 \\
{[ \pm 25]}\end{array}$ \\
\hline $\begin{array}{l}\text { ML-8b } \\
(8)\end{array}$ & $\begin{array}{c}0.90 \\
{[6.50]}\end{array}$ & $1360[ \pm 16]$ & & $\begin{array}{c}750 \\
{[ \pm 15]}\end{array}$ & $\begin{array}{c}1270 \\
{[ \pm 15]}\end{array}$ \\
\hline $\begin{array}{l}\text { ML-11a } \\
(11)\end{array}$ & $\begin{array}{c}0.01 \\
{[1.98]}\end{array}$ & $377[ \pm 18]$ & $\begin{array}{l}1496-1512(12.6 \%) \\
\mathbf{1 5 4 8 - 1 6 2 3}(\mathbf{5 5 . 6 \% )}\end{array}$ & $\begin{array}{c}1585 \\
{[ \pm 35]}\end{array}$ & $\begin{array}{c}435 \\
{[ \pm 35]}\end{array}$ \\
\hline $\begin{array}{l}\text { ML-11b } \\
(11)\end{array}$ & $\begin{array}{c}0.97 \\
{[1.98]}\end{array}$ & $1575[ \pm 15]$ & $529-574(68.2 \%)$ & $\begin{array}{c}551 \\
{[ \pm 20]}\end{array}$ & $\begin{array}{c}1470 \\
{[ \pm 20]}\end{array}$ \\
\hline
\end{tabular}

${ }^{1}$ Depth in wood from the exterior of the stem.

${ }^{2}$ Height/distance from the base.

Sample ages represent the difference between the year 2020 CE and the mean value of the selected range, with the corresponding error. Sample ages and errors were rounded to the nearest $5 \mathrm{yr}$. We used this approach for selecting calibrated age ranges and single values for sample ages in our previous articles on AMS radiocarbon dating of superlative angiosperms, especially of baobabs [6-22].

Dating results of samples. The two samples ML-1 originate from the end of the toppled and broken stem 1, which now has a horizontal length of $4.20 \mathrm{~m}$. The remaining part of stem 1 is quasi-cylindrical and has a diameter of $2.00-2.20 \mathrm{~m}$ with missing bark. The sample ML-1a was taken halfway between the exterior of stem 1 and the theoretical pith, at a depth of $0.51 \mathrm{~m}$ into the wood. It has a radiocarbon date of $1090 \pm 18 \mathrm{BP}$, which corresponds to a calibrated age of $1015 \pm 10$ calendar yr. The sample ML- $1 \mathrm{~b}$ was extracted from the theoretical pith of stem 1, at a distance of $4.20 \mathrm{~m}$ from the base. The radiocarbon date of $1602 \pm 17 \mathrm{BP}$ corresponds to a calibrated age of $1520 \pm 35$ calendar yr. This is the oldest dated sample originating from Makuri Lê boom. 
The two samples ML-8 were collected from the fallen and broken stem 8 , which now has a horizontal length of $10.90 \mathrm{~m}$. Its diameter at breast height is $\mathrm{dbh}=2.30 \mathrm{~m}$. Similarly, to samples ML-1, the sample ML-8a was extracted halfway between the exterior of stem 8 and its theoretical pith, while the sample ML-8b originates from the theoretical pith, both at a distance of $6.50 \mathrm{~m}$ from the stem base. The radiocarbon dates of the two samples are $930 \pm 19 \mathrm{BP}$ and $1360 \pm 16 \mathrm{BP}$. These values correspond to calibrated ages of $845 \pm 25$ and $1270 \pm 15$ calendar yr.

The samples ML-11 originate from the standing stem 11, which has a dbh $=3.05 \mathrm{~m}$ and is broken at the height of $6.2 \mathrm{~m}$. They were collected from a long crack in the stem at the height of $1.98 \mathrm{~m}$. Sample ML-11a consists of wood which was adjacent to the bark. However, the sample is not young as expected, but it has a radiocarbon date of $377 \pm 18 \mathrm{BP}$. This value corresponds to a calibrated age of $435 \pm 35 \mathrm{yr}$ and it shows that stem 11 stopped growing over 400 years ago. The deepest sample ML-11b has a radiocarbon date of $1575 \pm 15 \mathrm{BP}$, which corresponds to a calibrated age of $1470 \pm 20$ calendar yr. It was extracted from a depth of $0.97 \mathrm{~m}$ into the wood, while the theoretical pith at the sampling height of $1.98 \mathrm{~m}$ is positioned at a depth of $1.35 \mathrm{~m}$.

Age of Makuri Lê boom. According to stem dimensions/diameters, Makuri Lê boom consists of stems which belong to at least three generations. Four stems $(3,5,9,12)$ have diameters around $1 \mathrm{~m}(0.8-1.3 \mathrm{~m})$, five stems $(1,2,6,8,10)$ have diameters close to $2 \mathrm{~m}(2.0-2.8 \mathrm{~m})$ and three stems $(4$, $7,11)$ have diameters of at least $3 \mathrm{~m}(3.0-3.5 \mathrm{~m})$. As mentioned, the oldest dated sample was collected from the theoretical pith of stem 1, with a diameter of $2.2 \mathrm{~m}$, and has an age of $1520 \pm 35$ years, which should be very close to the age of this stem.

As detailed in our previous papers, extrapolation to the center of the largest stems would yield older ages. For similar reasons, we consider that the largest stems of Makuri Lê boom are around 2000 years old.

Architecture of the baobab. By our research, we have identified a new architecture, which enables African baobabs to reach old ages and large sizes. In this multi-stemmed architecture, the stems define at ground level a circle or an ellipse, with an empty space between them. We named it ringshaped structure (RSS). There are two subtypes of RSSs: the open RSS and the closed RSS $[9,12]$.

Makuri Lê boom exhibits an open RSS (Figure 3). In the open RSS, the stems are fused or knitted at the base, are pointed sideways, have cylindrical shapes and quasi-circular transversal sections $[9,12,16]$. 
Over time, stems may topple and die, while new stems emerge periodically from roots or from other fallen or broken stems. Such multistemmed and multi-generation baobabs with open RSSs are going through successive cycles of death and rebirth from their remains. In the case of open RSSs, the collapse and death of one or even of several stems does not usually affect the whole ring.

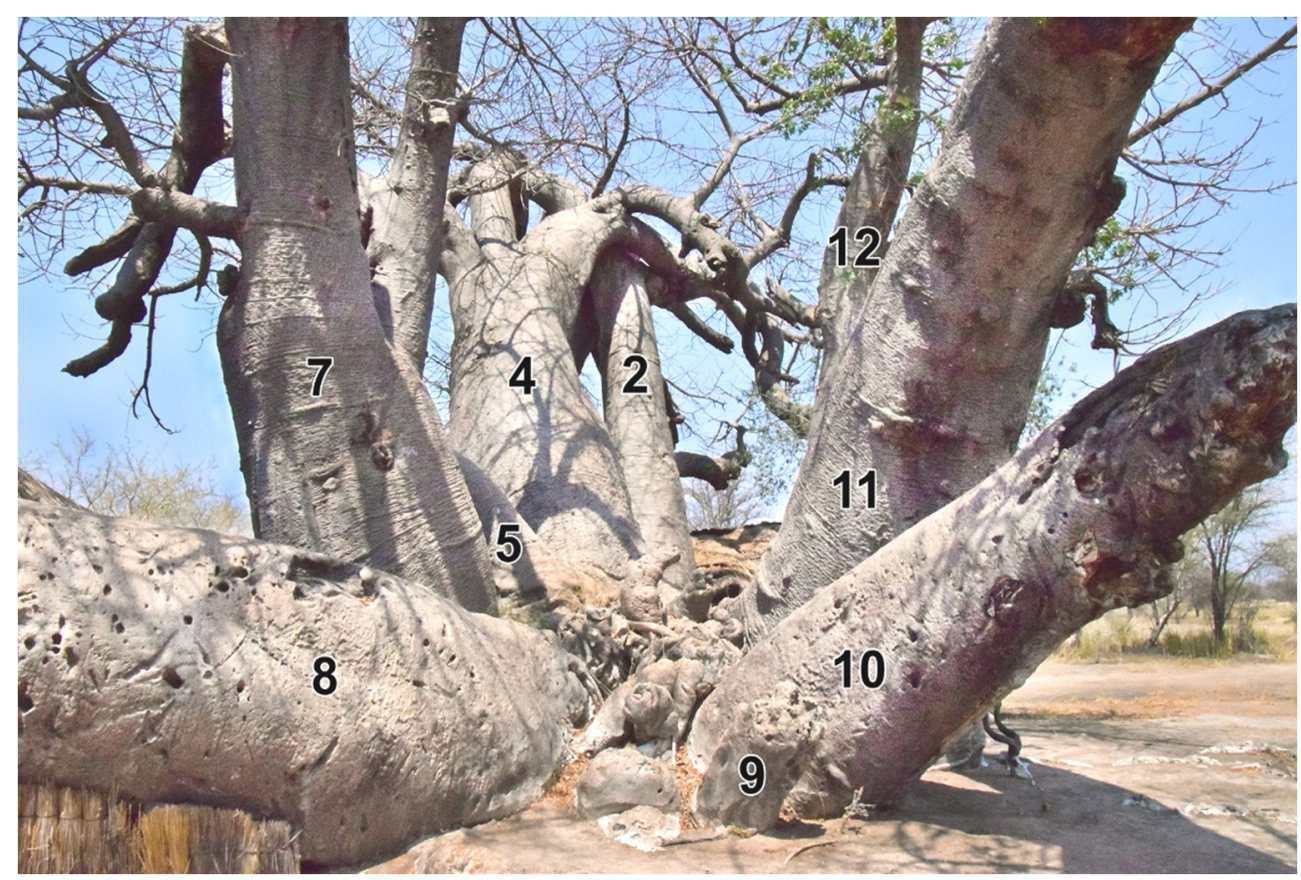

Figure 3. The photograph shows the common area from which the stems, that build the open ring-shaped structure, started growing.

Just like other famous very old baobabs with open RSSs, such as Dorslandboom or Glencoe, with toppled, standing and leaning knitted stems, some of them broken and a few regenerated with new shoots [12], Makuri Lê boom can be considered a kind of "Schrödinger's baobab", which is at the same time dead and alive. 


\section{CONCLUSIONS}

The research presents the AMS radiocarbon investigation results of the Makuri Lê boom, a very large and old African baobab from Nyae Nyae Conservancy, Namibia. The aim of the research was to determine the age and the architecture of this baobab. Makuri Lê boom is composed of 12 living stems of different dimensions and ages.

Six wood samples extracted from three different stems were processed and dated by AMS radiocarbon. Four samples were found to have ages greater than $1000 \mathrm{BP}$. The oldest dated sample has a radiocarbon date of $1602 \pm 17 \mathrm{BP}$, which corresponds to a calibrated age of $1520 \pm 35$ calendar yr. We consider that the largest stems of Makuri Lê boom are around 2000 years old. We also found that the largest and oldest stems stopped growing several centuries ago.

Makuri Lê boom exhibits an open ring-shaped structure, an architecture, which allows baobabs to reach very large sizes and old ages.

\section{EXPERIMENTAL SECTION}

Sample collection. Several tiny wood samples were extracted from predetermined positions of three stems with a sharp instrument. The samples were processed and investigated by AMS radiocarbon dating.

Sample preparation. The standard acid-base-acid pretreatment method was used for removing soluble and mobile organic components [23]. The pretreated samples were combusted to $\mathrm{CO}_{2}$ by using the closed tube combustion method [24]. Then, $\mathrm{CO}_{2}$ was reduced to graphite on iron catalyst, under hydrogen atmosphere [25]. Finally, the resulting graphite samples were analyzed by AMS.

AMS measurements. AMS radiocarbon measurements were performed at the NOSAMS Facility of the Woods Hole Oceanographic Institution (Woods Hole, MA, U.S.A.) by using the Pelletron ${ }^{\circledR}$ Tandem 500 kV AMS system. The obtained fraction modern values, corrected for isotope fractionation with the normalized $\delta^{13} \mathrm{C}$ value of $-25 \%$, were ultimately converted to a radiocarbon date.

Calibration. Radiocarbon dates were calibrated and converted into calendar ages with the OxCal v4.3 for Windows [26], by using the SHCal13 atmospheric data set [27]. 
ROXANA T. PATRUT, ADRIAN PATRUT, DEMETRA RAKOSY, LASZLO RAKOSY, DANIEL A. LÖWY, JENÖ BODIS, KARL F. VON REDEN

\section{ACKNOWLEDGEMENTS}

Authors would like to acknowledge Leon Tsamkxao $\neq$ Oma, interpreter, guide and research assistant at Tsumkwe Lodge, who led us to the soughtafter baobab and assisted the investigation. The research was funded by the Romanian Ministry of National Education CNCS-UEFISCDI under grant PNIII-P4-ID-PCE-2016-0776, Nr. 90/2017.

\section{REFERENCES}

1. G.E. Wickens, P. Lowe, "The Baobabs: Pachycauls of Africa, Madagascar and Australia", Springer, Dordrecht, 2008, pp. 232-234, 256-257, 295-296.

2. D.A. Baum, Ann. Missouri Bot. Gard.,1995, 82, 440-471.

3. J.D. Pettigrew, L.K. Bell, A. Bhagwandin, E. Grinan, N. Jillani, J. Meyer, E. Wabuyele, C.E. Vickers, Taxon, 2013, 61, 1240-1250.

4. G.V. Cron, N. Karimi, K.L. Glennon, C.A. Udeh, E.T.F. Witkowski, S.M. Venter, A.E. Assobadjo, D.H. Mayne, D.A. Baum, Taxon, 2016, 65, 1037-1049.

5. A. Petignat, L. Jasper, "Baobabs of the world: The upside down trees of Madagascar, Africa and Australia", Struik Nature, Cape Town, 2015, pp. 16-86.

6. A. Patrut, K.F. von Reden, D.A. Lowy, A.H. Alberts, J.W. Pohlman, R. Wittmann, D. Gerlach, L. Xu, C.S. Mitchell, Tree Physiol., 2007, 27, 1569-1574.

7. A. Patrut, D.H. Mayne, K.F. von Reden, D.A. Lowy, R. Van Pelt, A.P. McNichol, M.L. Roberts, D. Margineanu, Radiocarbon, 2010, 52(2-3), 717-726.

8. A. Patrut, K.F. von Reden, R. Van Pelt, D.H. Mayne, D.A. Lowy, D. Margineanu, Ann. Forest Sci., 2011, 68, 93-103.

9. A. Patrut, S. Woodborne, R.T. Patrut, L. Rakosy, D.A. Lowy, G. Hall, K.F. von Reden, Nature Plants, 2018, 4(7), 423-426.

10. A. Patrut, D.H. Mayne, K.F. von Reden, D.A. Lowy, R. Van Pelt, A.P. McNichol, M.L. Roberts, D. Margineanu, Radiocarbon, 2010, 52(2-3), 717-726.

11. A. Patrut, K.F. von Reden, D.H. Mayne, D.A. Lowy, R.T. Patrut, Nucl. Instrum. Methods Phys. Res., B, 2013, 294, 622-626.

12. A. Patrut, S. Woodborne, K.F. von Reden, G. Hall, M. Hofmeyr, D.A. Lowy, R.T. Patrut, PLOS One, 2015, 10(1): e0117193.

13. A. Patrut, S. Woodborne, K.F. von Reden, G. Hall, R.T. Patrut, L. Rakosy, J-M. Leong Pock Tsy, D.A. Lowy, D. Margineanu, Radiocarbon, 2017, 59(2), 435448.

14. A. Patrut, L. Rakosy, R.T. Patrut, I.A. Ratiu, E. Forizs, D.A. Lowy, D. Margineanu, K.F. von Reden, Studia UBB Chemia, 2016, LXI, 4, 7-20.

15. A. Patrut, R.T. Patrut, L. Rakosy, D.A. Lowy, D. Margineanu, K.F. von Reden, Studia UBB Chemia, 2019, LXIV, 2 (II), 411-419. 
16. A. Patrut, S. Woodborne, R.T. Patrut, G. Hall, L. Rakosy, C. Winterbach, K.F. von Reden, Forests, 2019, 10, 983-993.

17. A. Patrut, A. Garg, S. Woodborne, R.T. Patrut, L. Rakosy, I.A. Ratiu, PLOS One, 2015, 15(1): e0227352.

18. A. Patrut, K.F. von Reden, D.A. Lowy, D.H. Mayne, K.E. Elder, M.L. Roberts, A.P. McNichol, Nucl. Instrum. Methods Phys. Res., B, 2010, 268, 910-913.

19. A. Patrut, K.F. von Reden, P. Danthu, J-M. Leong Pock Tsy, R.T. Patrut, D.A. Lowy, PLOS One, 2015, 10(3): e0121170.

20. A. Patrut, K.F. von Reden, P. Danthu, J-M. Leong Pock-Tsy, L. Rakosy, R.T. Patrut, D.A. Lowy, D. Margineanu, Nucl. Instrum. Methods Phys. Res., B, 2015, 361, 591-598.

21. A. Patrut, R.T. Patrut, P. Danthu, J.-M. Leong Pock-Tsy, L. Rakosy , D.A. Lowy, K.F. von Reden, PLOS One, 2016, 11(1), e0146977.

22. R.T. Patrut, A. Patrut, J-M Leong Pock-Tsy, S. Woodborne, L. Rakosy, P. Danthu, IA. Ratiu, J. Bodis, K.F. von Reden, Studia UBB Chemia, 2019, LXIV, 4, 131-139.

23. I.U. Olsson, Radiometric Methods. In: B. Berglung, editor, "Handbook of Holocene palaeoecolgy and palaeohydrology", Wiley, Chichester, 1986, pp. 273-312.

24. Z. Sofer, Anal. Chem., 1980, 52(8), 1389-1391.

25. J.S. Vogel, J.R. Southon, D.E. Nelson, T.A. Brown, Nucl. Instrum. Methods Phys. Res., B, 1984, 5, 289-293.

26. C. Bronk Ramsey, Radiocarbon, 2009, 51, 337-360.

27. A.G. Hogg, Q. Hua, P.G. Blackwell, M. Niu, C.E. Buck, T.P. Guilderson, T.J. Heaton, J.G. Palmer, P.J. Reimer, R.W. Reimer, C.S.M. Turney, R.H. Zimmerman, Radiocarbon, 2013, 55(4), 1889-1903. 